\title{
ARAŞTIRMA/RESEARCH \\ İntrasitoplazmik sperm enjeksiyonu sikluslarında luteal faz desteğinde intramusküler ve vajinal progesteron kullanımının gebelik oranlarına etkisinin karşılaştırılması
}

Comparison of pregnancy rates with intramuscular and vaginal progesterone use for luteal phase support in intracytoplasmic sperm injection cycles

Murat Işıkalan¹, İbrahim Ferhat Ürünsak², Ghanim Khatib², Cihan Çetin², Mete Sucu², Turan Çetin²

${ }^{1}$ Siverek Devlet Hastanesi, Kadın Hastalıkları ve Doğum Bölümü, Sanlıurfa, Turkey

${ }^{2}$ Çukurova Üniversitesi Tıp Fakültesi, Kadın Hastalıkları ve Doğum Anabilim Dalı, Adana, Turkey

\section{Abstract}

Purpose: This study aimed to compare the pregnancy rates of intramuscular and vaginal progesterone use for luteal phase support in in vitro fertilization intracytoplasmic sperm injection and embryo transfer cycles done with gonadotropin releasing hormone analogs. Material and Methods: Sixty six patients undergoing in vitro fertilization -intracytoplasmic sperm injection and embryo transfer with controlled ovarian hyperstimulation were included. Thirty two patients were supplemented with vaginal gel (90 $\mathrm{mg}$ daily) and thirty four patients with intramuscular progesterone (50 $\mathrm{mg}$ daily) starting at the day on oocyte retrieval. $20 \mathrm{mIU} / \mathrm{mL}$ or above was considered positive for $\beta$-hCG. Positive $\beta$-hCG, clinical pregnancy and live birth rates were compared among these groups.

Results: In women undergoing intracytoplasmic sperm injection and embryo transfer, vaginal progesterone supplementation once a day beginning the day after oocyte retrieval resulted in comparable rates of positive $\beta$-hCG, clinical pregnancy and live birth rates with women supplemented with intramuscular progesterone.

Conclusion: The results of vaginal progesterone administration were similar with the results obtained with intramuscular progesterone. Vaginal progesterone use is a more tolerable method for patients.

Key words: in vitro fertilization, intracytoplasmic sperm injection, progesterone, luteal phase.

\section{Öz}

Amaç: Gonadotropin releasing hormon analogları (GnRHa) kullanilarak kontrollü ovarian hiperstimulasyon yapılan in vitro fertilizasyon - intrasitoplazmik sperm enjeksiyonu-embriyo transferi sikluslarında, luteal faz desteği için intramuskuler progesteron ve vajinal progesteron ile elde edilen gebelik oranlarını karșilaștırmaktır.

Gereç ve Yöntem: Çalışmaya kontrollü ovaryen hiperstimulasyon ile birlikte İn Vitro Fertilizasyon İntrasitoplazmik Sperm Enjeksiyonu - Embriyo Transferi yapilan 66 hasta dahil edildi. Oosit toplanmasinin ertesi gününden başlayarak 32 hastaya vajinal (günlük $90 \mathrm{mg}$ jel) ve 34 hastaya intramuskuler progesteron (günlük $50 \mathrm{mg}$ ) verildi. $20 \mathrm{mIU} / \mathrm{mL}$ ve üstü $\beta$-hCG değeri pozitif olarak kabul edildi. $\beta$-hCG pozitifligi, klinik gebelik ve canlı doğum iki grup arasında karşılaştırıldı.

Bulgular: İn Vitro Fertilizasyon - İntrasitoplazmik Sperm Enjeksiyonu ve Embriyo Transferi yapılan kadınlarda oosit toplanması günü başlanarak günde bir kere vajinal progesteron jel $(90 \mathrm{mg})$ verilmesi, günlük intramuskuler progesteron $(50 \mathrm{mg})$ verilmesi ile benzer oranlarda $\beta$-hCG pozitifliği, klinik gebelik ve canlı doğum oranları sağlamıştır.

Sonuç: Vajinal progesteron desteği sonuçları, intramuskuler progesteron desteğinden sonra elde edilen sonuçlarla benzerdir. Vajinal yolla progesteron kullanımı hastalar tarafindan da daha kolay tolere edilebilen bir metottur.

Anahtar kelimeler: In vitro fertilizasyon, intrasitoplazmik sperm enjeksiyonu, lüteal faz, progesterone. 


\section{GİRİ̧}

In vitro fertilizasyon (IVF) sikluslarında embriyonun implantasyon aşaması halen reprodüktif başarıyı sınırlayan en önemli adım olarak karşımıza çıkmaktadır. Embriyo implantasyonu, embriyo ve endometriyum arasındaki mükemmel bir senkronizasyonun sonucudur. Blastokistin implantasyonu ve gebeliğin sürdürülebilmesi için uygun bir endometriyum gerekmektedir. Endometriyumun uygun gelişimi için ovaryen steroidlere (östrojen ve progesteron) ihtiyaç vardır. Endometriyumun gelişimi folliküler fazda östrojen luteal fazda progesteron etkisiyle gerçekleşir. Östradiol folliküler fazda endometriyumun epitelyal, stromal ve glanduler proliferasyonunda rol oynar. Progesteron ise luteal fazda etkili olup, implantasyon dahil bir çok fonksiyon ile ilgilidir ${ }^{1}$. Doğal siklusların aksine, gonadotropinlerle indüklenmiş sikluslarda, erken luteal fazda suprafizyolojik östradiol ve progesteron düzeyleri endometrial gelişimde öne kaymaya neden olur; böylece implantasyon döneminde embriyo ve endometrial gelişim arasında asenkronizasyon oluşur

Ovulasyon indüksiyonu yapilan ve gonodotropin salgilatic1 hormon $(\mathrm{GnRH})$ agonisti kullanılan in vitro fertilizasyon-intrasitoplazmik sperm enjeksiyonu- embryo transferi (IVF-ICSI-ET) sikluslarında serum lüteinizan hormon $(\mathrm{LH})$ ve diğer hipofizer gonadotropin konsantrasyonları GnRH agonisti son dozundan itibaren en az 10 gün daha baskılanmış olarak kalır². Bu durum korpus luteum desteğinin ve etkinliğinin ortadan kalkması endişesini ortaya çıkarmıştır.

Yapılan çalışmalarda agonist kullanılan sikluslarda progesteron yapımının bozulduğu ve LH pulsatilitesinin baskılandığ1 gösterilmiştir ${ }^{3}$. IVF sikluslarında herhangi bir hormon replasmanı yapilmazsa luteal fazda östradiol (E2) ve progesteron düşük seviyelere inmektedir. Luteal fazdaki seks steroidlerindeki düşüklük yetersiz implantasyon ve gebelik oranlarıyla ilişkilendirilmiştir ${ }^{4}$. Çünkü, korpus luteum fonksiyonlarını devam ettirmek için hipofizer LH stimulasyonuna ihtiyaç duyar, LH yokluğunda prematur luteoliz meydana gelir. Bu veriler ile IVF sikluslarında luteal faz desteği rutin uygulama haline gelmiştir. Luteal faz desteği konusunda optimal bir protokol belirlenmemiştir ${ }^{5}$. Ancak hCG ve progesteron desteği verilen sikluslarda implantasyon ve gebelik oranlarının arttığı bildirilmektedir ${ }^{6}$. Literatürde progesteron kullanımı ile ilgili optimal protokol hala belirlenemediği için biz bu çalışmamızda, GnRH agonisti kullanılan IVF-ICSIET sikluslarında vaginal ve intramusküler progesteron kullanımının etkinliğini kendi klinik verilerimizde karşılaştırmayı amaçladık.

\section{GEREÇ VE YÖNTEM}

Çalışmamız Eylül 2009- Şubat 2010 tarihleri arasında Çukurova Üniversitesi Tip Fakültesi Kadın Hastalıkları-Doğum Kliniğinin Yardımla Üreme Merkezi Ünitesinde GnRH agonisti ile uzun protokol ve IVF-ICSI-ET uygulanan hastalar değerlendirmeye alınarak retrospektif olarak yürütüldü. Kadın yaşı 20 ile 40 yaş arası olan, dosya bilgilerinin tamamına ulaşılan hastalar ve ilk başvurduklarında öyküleri alınıp, fizik muayene ve pelvik muayene yapilarak dosyalarına kayıt yapılan hastalar değerlendirmeye alındı.

Değerlendirilmeye alınan her hastanın siklusun 2 . veya 3. günü bazal serum follikül stimulan hormon (FSH), LH, E2, prolaktin, tiroid stimulan hormon (TSH), serbest T3, T4 seviyeleri ölçülmüştür. Çalışmaya adetin 2-3. günü ölçülen serum FSH 10 $\mathrm{IU} / \mathrm{ml}$ ve E2 $80 \mathrm{pg} / \mathrm{ml}$ üstünde olan hastalar dahil edilmedi. $\mathrm{Bu}$ hastaların histerosalpingografi ile endometrial kavitesi ve tubaları değerlendirilmiştir. Hastalar; erkek faktörü, yaş faktörü (38 ve üstü yaş grubu), açıklanamayan faktör, tubal faktör endikasyonları nedeniyle IVF-ICSI-ET için hazırlanmıșlardır. Bu kriterleri karșılayan 66 infertil çift değerlendirmeye alındı. Bir hasta çalışmaya sadece bir kere dahil edilmiştir, takip eden diğer siklusları çalışmaya alınmamıştır. Çalışma için Çukurova Üniversitesi Tip Fakültesi Araştırma Etik Kurul'undan onay alınmış (2011/6/19) ve hastalar verilerinin kullanılması ile ilgili onam vermişlerdir.

\section{Ovulasyon indüksiyon protokolü}

Çalışmamızda tüm hastalara GnRH agonisti ile uzun protokol uygulanmıştır. Tedaviye bir önceki siklusun 21. gününde $\mathrm{GnRH}$ agonisti (Triptorelin (Decapeptyl ${ }^{\text {TM}}$ ) 0,1 $\mathrm{mg} /$ gün dozunda subkutan) başlanmıştır. Hastalar adetin 2-3. gününde hipofizer down regulasyonun olup olmadığının belirlenmesi için çağrılmıştır. Transvajinal ultrasonografide 10 mm'den büyük antral folikül olmaması, serum E2'nin $60 \mathrm{pg} / \mathrm{ml}$ altında olmasi ve endometrial kalınlığın $5 \mathrm{~mm}$ altında olması down regulasyon olarak kabul edilmiştir. Hastaya rekombinant FSH (rFSH) ile ovulasyon indüksiyonuna başlanmıştır. 
Prematur LH yükselmelerini önlemek amaciyla hCG gününe kadar $\mathrm{GnRH}$ agonistinin dozu yarlya düşülerek devam ettirilmiştir. Gonadotropin dozu; hastanın yaşı, kilosu, bazal E2, FSH seviyesine ve varsa daha önceki ovulasyon indüksiyonu cevabina bakılarak belirlenmiştir. Her gün aynı saate 5 gün gonadotropin uyguladıktan sonra follikül gelişimi, serum E2 seviyesi belirlenmek üzere hastalar kontrole çağrilmıştır. Hastanın cevabina göre gonadotropin dozu tekrar ayarlanmış ya da aynı dozda idame ettirilmiştir. Seri ultrasonografi kontrolleri ve serum E2 kontrollerinden sonra 18 mm'den büyük en az 2-3 follikül gelişen hastalarda oosit toplama işlemi planlanmıştır. Hastalara hCG (5000 -10000 IU intramusküler) ya da rekombinant hCG $(250 \mu \mathrm{g}$ subcutan) uygulanmıştır.

\section{Oosit toplanması}

Oosit toplama işlemi hCG dozundan itibaren 35-36. saatte gerçekleştirilmiştir. Laboratuvar hazırlığ1 yapilip, hasta operasyon masasina usulüne uygun olarak hazırlanmıştır. Anestezi ekibi tarafından sedasyon anestezisi uygulanmıştır. Steril serum fizyolojikle vulva yıkanarak temizlenmiştir. Steril spekulum uygulanarak vajen serum fizyolojik ile yıkanmıştır.

Transvajinal ultrason eşliğinde, standart prosedürler kullanılarak oosit aspirasyon işlemi yapılmıştır. Aspire edilen follikül sıvısı daha önceden 1sıtılmış olan falkon tüplerde toplanmış ve hemen bitişikteki embriyoloji laboratuvarına teslim edilmiştir. OPU yapılan hastaların anestezi doktoru tarafindan vital bulguları takip edilmiştir. Kanama kontrolünü takiben hasta yatak istirahatine alınmıştır. İşlemin yapıldığ1 günden embriyo transfer gününe kadar günde 2 kez tetrasiklin antibiyotik profilaksisi uygulanmıştır. Gerekli işlemlerden geçirilen toplanan oositler dört kuyulu petrinin değissik gözlerine dağıtılmıştır. Oositler gelişimine göre GV, MI, MII olarak sınıflandırılmıştır. MII (matur oosit) ICSI için hazırlanmıştır.

GV ve MI'ler in vitro oosit maturasyon işlemine alınarak 16-24 saat içerisinde polar cisimciklerini atmaları beklenmiştir. ICSI için hazırlanan oositler aynı medyumda $30-60$ dakika $37^{\circ} \mathrm{C}$ ve $\% 5 \mathrm{CO}_{2}$ içeren ortamda inkubasyona bırakılmıştır. Bu arada erkek eşten alınan semen, işlemden geçirilerek yüzdürülmüştür. Hastalar 3-5 günlük cinsel perhizden sonra mastürbasyon yaparak semen vermişlerdir. Sperm örneği alındıktan sonra uygun koşullarda androloji laboratuvarına teslim edilmiştir.

\section{ICSI işlemi}

Uygulama, damlacıklar halinde yerleştirilen

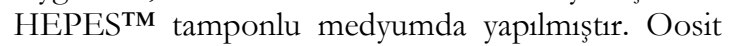
sayısına göre bu damlacıklar petri kabına belli bir düzenle konulmuştur. Spermlerin konulacağ1 polyvinlypyrrolidone (PVP) damlacığı da bunların kenarına konularak hepsinin üzeri mineral yağ ile kapatılmıştır. PVP içine inceltilmiş pastör pipetiyle sperm süspansiyonun kenarından aspire edilen spermler konulmuştur. Tutucu (holding) ve injeksiyon (ICSI) pipetleri tutuculara takıldıktan sonra joy sticklerle uygun pozisyon almalar1 sağlanmıştır. Hazırlanan ICSI petrisi yerleştirilmiştir. ICSI pipeti ile PVP alanından bir sperm kuyruğu kırılarak hareketsiz hale getirilerek pipet içerisine çekilmiştir. Daha sonra oosit yanına getirilmiştir. MII oositler ICSI'ye alınmıştır. Oositin kutup cisimciği (polar body) saat 6 veya 12 hizasina getirilmiştir. Saat 3 hizasından oosite yaklaştırılmıştır. Tutucu pipet yardımıyla oosit tutulmuştur. ICSI pipeti ile oosit içersine girilip biraz sitoplazma aspire edilmiş ve ardından spermle beraber bu sitoplazma bırakılmıştır. Böylece ICSI tamamlanmıştır. Yapılan bu işlemler sırasında herhangi bir teknik zorlukla karşıllaşılmamıştır.

\section{Luteal faz desteği}

32 Hasta vajinal yolla progesteron jel (Crinone ${ }^{\text {TM}}$ ) (günde bir kez $90 \mathrm{mg}$ ), 34 hasta intramuskuler progesteron (Progynex ${ }^{\mathrm{TM}}$ ) (günlük $50 \mathrm{mg}$ ) uygulamıştır. İntramuskuler progesteron alanlar 1. gruba, vajinal progesteron alanlar 2. gruba dahil edilmiştir. Tedaviye oosit toplandığ1 gün başlanmıştır. $\beta$-hCG sonucuna göre tedavinin devamına karar verilmiştir. $\beta$-hCG negatif ise tedavi kesilmiştir. $\beta$-hCG pozitif ise progesteron desteğine 12. gebelik haftasına kadar devam edilmiştir. Ayrıca oosit toplandiktan sonra hastalar 3 gün süreyle günlük $16 \mathrm{mg}$ metilprednisolon tablet (Prednol ${ }^{\mathrm{TM}}$ ) almışlardır.

\section{Embriyo transferi}

Oosit toplanmasindan itibaren 3. gün embriyo transferi uygulanmıştır. Hastalar mesaneleri dolu olarak dorsal litotomi pozisyonunda operasyon masasına hazırlanmıştır, embriyo transferi için uygun ön hazırlık yapılmıştır. Kateterin servikal kanaldan uterin kaviteye geçişini zorlaştıran uterusun aşırı 
anteversiyon ya da retroversiyon durumunda serviks tenakulum ile nazikçe tutulduktan sonra uterusun pozisyonu düzeltilmiştir. Servikal stenoz durumunda kanal nazikçe dilate edilmiştir. Embriyolar inkübatörden çıartılarak stereo diseksiyon mikroskobu altında kontrol edilmiş ve skorlanarak kaydedilmiştir. 1-2 saat önce 1sıtılan Transfer kateteri etüvden çıarılmıştır. 1 ml'lik enjektöre transfer medyumu çekilmiş ve kateterden boşaltılarak kateterin içi yıkanmıştır. Abdominal ultrason eşliğinde, Labotect kateter ${ }^{\mathrm{TM}}$ kullanılarak, embriyolar kavitede uygun yere birakılmışlardır. Ultrasonografide kavitedeki damlanın varlığı kontrol edilmiştir. Kateter nazikçe geri çekilip embriyoloğa teslim edilmiştir. Tüm embriyoların verilip verilmediğinden emin olmak için kateter tekrar kontrol edilmiştir. Transabdominal ultrasonografi ile embriyo transferi sırasındaki endometrial kalınlık ölçülmüştür. Transferin süresi, zamanı, güçlüğü ve verilen embriyo sayısı ve kalitesi kaydedilmiştir.

Transferden sonra hasta 5 dakika dinlendirildikten sonra yatağına alınmıştır. 2 saatlik istirahatten sonra evine gönderilmiştir. Tüm hastaların oosit toplandıktan 3 gün sonra yani embriyo transfer günü ve embriyo transferinden 12 gün sonra serum progesteron düzeylerine bakılmıştır. Hastalara embriyo transferinden 12 gün sonra $\beta$-hCG bakılmıştır. $20 \mathrm{mIU} / \mathrm{mL}$ ve üstü $\beta$-hCG değerleri pozitif kabul edilmiştir.

\section{Gebelik sonuçları}

Klinik gebelik, $\quad \beta$-hCG pozitifliği ile birlikte,ultrasonda gestasyonel sac yada fetal polun görünmesi ile gebeliğin doğrulanması olarak kabul edildi. Biyokimyasal abortus, serum biyokimyasında $\beta$-hCG pozitifliği saptanan ancak ultrasonografide gebelik saptanmayan ve daha sonra $\beta$-hCG pozitifliği kaybolan hastalar olarak tanımlandı. Klinik abortus ise gebeliğin 6 . haftasında yapilan transvajinal ultrasonografi sonrasi fetal kardiak aktivite görüldükten sonra gerçekleşen abortus olarak tanımland.

\section{İstatistik}

Verilerin istatistiksel analizinde SPSS 19.0 paket programı kullanıldı. Kategorik ölçümler sayı ve yüzde olarak, sayısal ölçümlerse ortalama ve standart sapma (gerekli yerlerde ortanca ve minimum maksimum) olarak özetlendi. Kategorik ölçümlerin gruplar arasında karşılaştırılmasında Ki Kare test istatistiği kullanıldı. Gruplar arasında sayısal ölçümlerin karşılaştırılmasında varsayımların sağlanması durumunda Bağımsız gruplarda $\mathrm{T}$ testi, varsayımların sağlanmaması durumunda ise Mann Whitney U testi kullanıldı. Tüm testlerde istatistiksel önem düzeyi 0,05 olarak alındı.

\section{BULGULAR}

Grup 1 ve grup 2'deki hastaların infertilite nedenleri tablo 1'de gösterilmiştir. Gruplar arasında infertilite etyolojisi açısından istatistiksel olarak anlamlı fark saptanmamıştır.( $(p>0.05)$. Çalışmaya katılan her iki grup arasında yaş ve infertilite süresi açısından anlamlı fark saptanmadi (Tablo 2). Her iki grupta 3.gün FSH ve E2 düzeyleri bazal olarak kabul edildi. Her iki grup arasinda bazal FSH, bazal E2,ortalama kullanilan gonadotropin dozu, indüksiyon süresi, matür follikül sayısı, transfer edilen embriyo sayısı, hCG gününde E2 seviyelerinde anlamlı farklılık saptanmamıştır (Tablo 3).

Çalışmadaki tüm hastalara bakıldığında 66 hastanın 19 (\% 28.7) tanesinde 12. gün $\beta$-hCG pozitifliği saptandi. Grupların gebelik oranlarında istatistiksel olarak anlamlı fark saptanmadı ( $p>0,05)$.(Tablo 4) Çalışmamıza dahil olan hiçbir hastada ektopik gebelik oluşmamıştır. Gruplar arasında endometriyal kalınlık açısından anlamlı fark bulunmaz iken ET günü endometriyal kalınlık açısından anlamlı fark bulunmad1 $(\mathrm{p}=0,005)$ (Tablo 5). Grupların progesteron düzeyleri arasinda hCG gününde fark saptanmazken, 12. günde sinırda anlaml,, ET gününde ise anlamlı fark olduğu bulunmuştur. (Tablo 6)

Gebelik oluşan ve oluşmayan sikluslar gruplarından bağımsız olarak karşılaştırıldığında kadın yaşı, erkek yaşı, ortalama kullanılan gonadotropin miktarları, bazal E2 ve FSH düzeyleri, indüksiyon süresi, matür follikül sayıs1, hCG gününde E2 ve progesteron seviyelerinde ve ET gününde progesteron seviyelerinde anlamlı farklılık saptanmamıştır. Ancak 12.gün progesteron düzeyleri gebelik oluşan grupta anlamlı olarak yüksek bulunmuştur (gebelik oluşanlarda:23.16 \pm 16.7 , gebelik oluşmayanlarda $7.22 \pm 12.8 \mathrm{p}<0.005)$. 
Tablo 1. Hastaların infertilite etyolojisi

\begin{tabular}{|l|c|c|}
\hline İnfertilite etyolojisi & $\begin{array}{c}\text { Grup I } \\
\mathbf{n ( \% )}\end{array}$ & $\begin{array}{c}\text { Grup II } \\
\mathbf{n}(\mathbf{\%})\end{array}$ \\
\hline Erkek faktörü & $10(\% 29.4)$ & $9(\% 28.8)$ \\
\hline Tubal faktör & $3(\% 8.8)$ & $3(\% 9.1)$ \\
\hline Açıklanamayan & $21(\% 61.7)$ & $20(\% 62.1)$ \\
\hline
\end{tabular}

Tablo 2. Grupların kadın-erkek yaşı ve infertilite süreleri

\begin{tabular}{|l|c|c|c|}
\hline Ölçümler & $\begin{array}{c}\text { Grup I } \\
\text { Ortalama } \pm \text { SS } \\
\text { (Min-Maks) }\end{array}$ & $\begin{array}{c}\text { Grup II } \\
\text { Ortalama } \pm S S \\
\text { (Min-Maks) }\end{array}$ & p değeri \\
\hline Kadın yaş1 & $33.14 \pm 5.96$ & $32.25 \pm 5.00$ & 0,512 \\
& $(18-43)$ & $(24-44)$ & 0,290 \\
\hline Erkek yaş1 & $34.28 \pm 5.55$ & $35.24 \pm 5.25$ & $(24-50)$ \\
\hline İnfertilite Süresi (ay) & $(25-51)$ & $101.25 \pm 60.03$ & 0.132 \\
& $(1.41 \pm 61.62$ & $(12-252)$ & \\
\hline
\end{tabular}

Tablo 3. İntramuskuler ve vajinal progesteron kullanan grupların karşılaştırılması

\begin{tabular}{|c|c|c|c|}
\hline & $\begin{array}{c}\text { Grup I } \\
\text { Ortalama } \pm \text { SS } \\
\text { Medyan(Min-Maks) }\end{array}$ & $\begin{array}{c}\text { Grup II } \\
\text { Ortalama } \pm \text { SS } \\
\text { Medyan(Min-Maks) }\end{array}$ & $\mathrm{p}$ değeri \\
\hline Bazal FSH (mIU/ml) & $\begin{array}{c}6.59 \pm 1.61 \\
6.74(3,69-9.62)\end{array}$ & $\begin{array}{c}6.73 \pm 1.91 \\
6.67(3.58-11.8)\end{array}$ & 0.487 \\
\hline Bazal E2 (pg/ml) & $\begin{array}{c}41.7 \pm 22.07 \\
38.9(7.63-136.3)\end{array}$ & $\begin{array}{c}44.03 \pm 27.73 \\
39.08(12.44-169.7) \\
\end{array}$ & 0.878 \\
\hline $\begin{array}{l}\text { Ortalama kullanılan Gonadotropin dozu } \\
\text { (IU) }\end{array}$ & $\begin{array}{c}1960 \pm 727 \\
1800(1050-5025)\end{array}$ & $\begin{array}{c}2039 \pm 869 \\
1875(1050-5025)\end{array}$ & 0.944 \\
\hline $\begin{array}{l}\text { hCG gününe kadar indüksiyon } \\
\text { süresi(gün) }\end{array}$ & $\begin{array}{c}10.2 \pm 1.80 \\
10(7-15)\end{array}$ & $\begin{array}{c}10.3 \pm 2.53 \\
10(6-18)\end{array}$ & 0.861 \\
\hline Matur folikül sayısı & $\begin{array}{l}4.5 \pm 2.1 \\
4(1-10)\end{array}$ & $\begin{array}{l}4.8 \pm 2.6 \\
5(1-14)\end{array}$ & 0.634 \\
\hline Transfer edilen embriyo sayısı & $\begin{array}{c}1.94 \pm 0.85 \\
2(1-3)\end{array}$ & $\begin{array}{c}1.56 \pm 0.80 \\
1(1-3)\end{array}$ & 0.059 \\
\hline hCG Günündeki E2 düzeyi (pg/ml) & $\begin{array}{c}1306 \pm 1260 \\
927(22-5775)\end{array}$ & $\begin{array}{c}1161 \pm 897 \\
773(37-3785) \\
\end{array}$ & 0.817 \\
\hline
\end{tabular}

Tablo 4. Grupların gebelik oranları

\begin{tabular}{|l|c|c|c|}
\hline & $\begin{array}{c}\text { Grup I } \\
\mathbf{n}(\mathbf{\%})\end{array}$ & $\begin{array}{c}\text { Grup II } \\
\mathbf{n}(\mathbf{\%})\end{array}$ & p değeri \\
\hline$\beta$-hCG Pozitifliği & $10(\% 29.4)$ & $9(\% 28.1)$ & $>0.05$ \\
\hline Biyokimyasal Abortus & $2(\% 5.8)$ & $2(\% 6.2)$ & $>0.05$ \\
\hline Klinik Abortus & $1(\% 2.9)$ & $1(\% 3.1)$ & $>0.05$ \\
\hline Klinik gebelik oranı & $7(\% 20.5)$ & $6(\% 18.7)$ & $>0.05$ \\
\hline Canlı doğum oranı & $6(\% 17.6)$ & $5(\% 15.6)$ & $>0.05$ \\
\hline
\end{tabular}

Tablo 5. Grupların endometrial kalınlık ölçümleri

\begin{tabular}{|l|l|l|l|}
\hline & $\begin{array}{l}\text { Grup I } \\
\text { Ortalama } \pm S S \\
\text { (Min-Maks) }\end{array}$ & $\begin{array}{l}\text { Grup II } \\
\text { Ortalama } \pm S S \\
\text { (Min-Maks) }\end{array}$ & p değeri \\
\hline 12.gün endometrial kalınlık $(\mathrm{mm})$ & $11.11 \pm 1.74(7.3-14)$ & $9.79 \pm 2.20(6.6-16.1)$ & 0.005 \\
\hline ET günü endometrial kalınlık $(\mathrm{mm})$ & $11.40 \pm 1.58(8.20-14.6)$ & $11.05 \pm 1.99(7.60-15)$ & 0.423 \\
\hline
\end{tabular}


Tablo 6. Grupların progesteron düzeyleri

\begin{tabular}{|l|c|c|c|}
\hline & $\begin{array}{c}\text { Grup I } \\
\text { Ortalama } \pm \text { SS } \\
\text { Medyan(Min-Maks) }\end{array}$ & $\begin{array}{c}\text { Grup II } \\
\text { Ortalama } \pm \text { SS } \\
\text { Medyan(Min-Maks) }\end{array}$ & p değeri \\
\hline 12.gün kanda progesteron düzeyi (ng/ml) & $7.8 \pm 15.8$ & $6.54 \pm 9.03$ & 0.56 \\
& $0.72(0.28-60)$ & $1.26(0.33-34.05)$ & 0.375 \\
\hline hCG günü kanda progesteron düzeyi $(\mathrm{ng} / \mathrm{ml})$ & $0.53 \pm 0.23$ & $0.50 \pm 0.26$ & $0.37(0.15-1.10)$ \\
\hline ET günü kanda progesteron düzeyi $(\mathrm{ng} / \mathrm{ml})$ & $0.55(0.20-1.05)$ & $47.32 \pm 15.00$ & 0.007 \\
\hline
\end{tabular}

\section{TARTIŞMA}

Daya ve Gunby tarafindan yapılan bir metaanalizde hCG veya progesteron kullanıminin IVF sikluslarında gerekli olduğu gösterilmiştir ${ }^{7}$. Bu metaanalizde hCG ve progesteron desteği de karşılaştırılmıştır. Progesterona hCG ilave edilmesinin, tek başına progesterona bir üstünlüğü gösterilememiștir. Bu çalıșmada en önemli veri hCG ilave edilen grupta OHSS oranlarındaki bariz artıştır.

Luteal faz desteği için progesteron kullanırken veriliş yolu, yüksek gebelik oranı sağlamanın yanı sıra hasta açısından en kullanışlı ve tolere edilebilecek şekilde olmalıdır. Oral progesteron kullanımında kötü absorbsiyon oranları izlendiği için kolay kullanım avantaj1 olsa da güncel çalışmalar daha çok intramusküler ve vajinal progesteron üzerine odaklanmıştır ${ }^{7}$.

Ayrıca oral mikronize progesteron, intramüsküler hCG veya progesteron ile karşılaştırıldığında önemli ölçüde düşük gebelik ve implantasyon oranlarına, ortaya çıkan metabolitleri nedeniyle daha fazla yan etkiye (sedasyon gibi) neden olmaktadır. Bu nedenle luteal fazda oral progesteron desteğinden kaçınılması önerilmektedir.

2002'de yapılan bir metaanalizde de, GnRH agonist kullanımı ile yapılan IVF sikluslarının luteal fazında intramuskuler veya vajinal progesteron ve hCG desteğinin plasebo ile karşılaştırılmasında, progesteron veya hCG desteği yapılan sikluslarda gebelik oranları önemli ölçüde yüksek bulunmuştur ${ }^{2}$. $\mathrm{Bu}$ metaanalizde, intramuskuler ve vajinal progesteron kullanımının karşılaştırıldığ 5 prospektif randomize çalışma değerlendirilmiş, klinik gebelik ve doğum oranları intramuskuler kullanımda önemli ölçüde yüksek bulunmuştur (rölatif risk değerleri: klinik gebelik oranı 1.33 (95\% GA 1.02-1.75), doğum oranı $2.06 \quad(95 \%$ GA $1.48-2.88))$. İntramuskuler kullanımda, 25 ile $100 \mathrm{mg} /$ gün aras1 değişen değişik dozların, sonucu etkilemesi açısından önemli bir farklılığa neden olmadığ bildirilmiştir. Yine 2004 Cochrane sistematik derlemesinde 59 çalışma değerlendirilmiş, vajinal veya intramuskuler progesteron desteğinin yapıldığı sikluslarda daha yüksek devam eden gebelik oranları tespit edilmiştir?.

IVF-ICSI-ET sikluslarında luteal faz desteği için progesterona östrojen eklemenin gebelik oranlarını arttırmada yararı olmadığını gösteren çalışmalar mevcuttur, ancak bu konudaki çalışmalar henüz yetersizdir ${ }^{8}$.

Geleneksel olarak, yakın zamana kadar intramuskuler progesteron enjeksiyonları luteal faz desteği için en sık kullanılan form olsa da, enjeksiyon yerinde ağn1, sellülit yada apse gelişimi, nadir ama ciddi sistemik yan etkiler ve uygulama yapmak için başka birisine ihtiyaç duyulması gibi dezavantajları vardir $^{9-11}$. IVF-ICSI-ET sikluslarında progesteron desteği için ideal formulasyon yüksek gebelik oranları sağlamalı, uygulaması kolay olmalı ve yan etkilileri az olmalıdır. Progesteronun vajinal formunun hepatik ilk geçiş etkisi olmaması, çabuk absorbe olması ve rölatif yüksek biyoyararlınımlı oluşu gibi avantajlar vadır. Bunun yanısıra, vajinal progesteron daha iyi tolere edilir ve hastalar tarafindan daha fazla tercih edilmektedir ${ }^{12,13}$. Ancak en önemli avantaj1, uterin ilk geçiş etkisi olarak da bilinen, lokal endometrial etkisidir. Vajinadan uterusa direk transport olmasindan dolay1, dolaşımdaki düşük progesteron seviyelerine rağmen, yüksek endometrial konsantrasyonlara ulaşıllır. Crinone $^{\mathrm{TM}}$ vajinal duvardan 24 saatten fazla bir süre kontrollü ve sürekli ilaç salınımı yapan, $90 \mathrm{mg}$ mikronize progesteron içeren bir jeldir. $\mathrm{Bu}$ ilaç ovaryen fonksiyonları olmayan kadınlarda donör 
yumurta sikluslarında luteal faz desteği için kullanılmıștır. Günde bir kez $90 \mathrm{mg}$ ya da günde iki kez 90 mg günlük dozlarının günlük 100 mg intramuskuler progesteron ile benzer gebelik oranları sağladığı bulunmuştur.

Daha önce yapılan bir çok çalışmada vajinal progesteronun, intramuskuler progesterona oranla etkisi mukayese edilmiştir fakat hiçbiri prospektif, randomize, yaş katmanlarına uygun şeklinde ayrılmamış ve yeteri kadar güçlü kesin sonuçlar vermemiştir. Luteal faz desteği için vajinal progesteron ile intramuskuler progesteronu karşılaştıran bir çok yeni meta-analiz her iki yolun gebelik sonuçları bakımından eşit etkili olduğunu göstermiştir ${ }^{14}$

Prospektif, çift kör, randomize, bir çalışmada Abate ve ark., intramusküler ve vajinal progesteronu karşılaştırmışlar ve tubal faktör nedeniyle infertilitesi olan 156 hastaya ya intramusküler progesteron (50 $\mathrm{mg})$ ya da vajinal progesteron jel (90 mg) vermişlerdir ${ }^{15}$. Kontrol grubu ise intramusküler sodyum klorür solüsyonu almıştır. Progesteron seviyesi ve gebelik hızı intramusküler grupta diğer gruplardan daha yüksek bulunmuştur ve intamuskuler yolun vajinal yola göre daha üstün olduğu savunulmuştur.

Diğer bir randomize çalışmada, 201 hastaya vajinal jel (90 mg/gün) ve intramusküler (50 mg/gün) progesteron luteal destek için verilmiştir ${ }^{12}$. İntramusküler progesteron desteği yapılan hastalarda vajinal jel alanlara göre daha yüksek embriyo implantasyonu, klinik gebelik ve canlı doğum oranları izlenmiştir. Retrospektif bir çalışmada vajinal jel verilen gruplarda diğer gruplardan daha kötü sonuçlar bildirilmiștir ama bu çalıșmanın kısıtlılığ1 vajinal progesteron alan hastaların sayısının az olması ve kötü prognostik faktörlere sahip olması nedeniyle tartışılabilirir ${ }^{16}$.

Chantilis ve ark, vajinal ve günlük intramuskuler progesteron alan grupların sonuçlarını pozitif BhCG ve klinik gebelik oranları açısından benzer bulmuşlardır ${ }^{17}$.

16 IVF merkezinden vajinal jel (Crinone \%8, 90 $\mathrm{mg} /$ gün) verilen 1000 siklusun sonuçları değerlendirilmiş ve SART (Society of Assisted Reproductive Technologies Register) sonuçlarıla karşılaştırılmıştır. Buna göre, rutin protokol ve vajinal jel verilmesi arasında fark bulunamamıştır ${ }^{18}$. Ayrıca, vajinal yol çalışmadaki hastalar tarafindan daha kullanışlı ve daha az ağrılı olarak bildirilmiştir.
Yanushpolsky ve ark, prospektif bir çalışmada vajinal jel ve intramuskuler progesteron kullanımını karşılaştırmışlar ve embriyo transfer başına benzer canlı doğum oranları izlemişlerdir ${ }^{19}$. Bu çalışmada daha önceden intramuskuler progesteron deneyimi olan hastalar vajinal yolu daha kullanışlı ve daha az ağrilı olarak değerlendirmişlerdir.

Bizim çalışmamızda embriyo transfer sonrası 12 . gün $\beta$-hCG pozitifliği yönünden her iki grupta istatistiksel olarak anlamlı fark saptanmadı ( $\mathrm{p}>0.05)$. Ayrıca klinik gebelik, klinik ve biyokimyasal abortus oranları açısından da iki grup arasında istatistiksel olarak anlamlı farklılık saptanmadı ( $\mathrm{p}>0.05)$.

IVF sikluslarında intramuskuler ve vajinal progesteronun mukayese edildiği bir çalışmada endometrial morfoloji ve vaskularite araştırılmış, intramuskuler progesteron $(100 \mathrm{mg} /$ gün) ya da vajinal progesterone $(200 \mathrm{mg} /$ gün) endometrium üzerinde benzer etkiler göstermişlerdir ${ }^{20}$.

206 hasta üzerinde yapılan prospektif bir çalışmada midluteal serum progesteron düzeyi intramuskuler grupta anlamlı olarak yüksek bulunmuştur ${ }^{17}$. Buna rağmen her iki grupta da benzer gebelik oranları saptanmıştır.

2010 y1lında yapılan ve 544 IVF hastasını kapsayan retrospektif bir çalışmada luteal faz desteği amaçlı intramuskuler progesteron kullanan grup ile vajinal progesteron kullanan grup karşılaştırılmış ve hCG günü bakilan E2 ve progesteron düzeyleri arasinda fark saptanmamıştır ${ }^{21}$. Aynı çalışmada vajinal ve intramuskuler luteal faz desteği alan hastalarda ortalama luteal faz progesteron düzeyleriyle pozitif gebelik testi arasında pozitif korelasyon tespit edilmiştir. Bizim çalışmamızda da hCG günü bakılan E2 ve progesteron düzeyleri arasında istatistiksel olarak anlamlı fark saptanmamıştır $(\mathrm{p}=0.817)$.

Çalışmamızda $\beta$-hCG pozitif saptanan hastalarla, $\beta$ hCG negatif saptanan hastaların ET sonras1 12.gün progesteron düzeylerine bakıldığında fark beklendiği üzere anlamlı bulunmuştur $(\mathrm{p}<0.001) .426$ hastay1 kapsayan ve ülkemizde yapılan bir çalışmada intramuskuler ve vajinal progesteron kullanan hastalar arasında 12. gün endometrial kalınlık ve E2 düzeyi arasında anlamlı bir farklılık saptanmamıştır ${ }^{22}$. Çalışmamızda da kullanılan 12.gün E2 düzeyleri arasında gruplar arasinda istatistiksel olarak anlamlı bir farklılık saptanmamıştır.

Endometriyal kalınlık ile gebelik oranları arasında ilişki olduğu düşünülmektedir ${ }^{23}$. Vajinal 
progesteronun ET sonras1 7-9. günlerde endometrial kalınlık ve hormonal parametrelere olan etkisinin araştırıldı̆̆ bir çalışmada; progesteron desteği alan ve gebelik oluşmayan IVF hastaları ile başarısız fertilizasyon nedeniyle progesteron alamayan hastalar karşılaştırılmıştır 22 . Bu iki grup aynı zamanda gebelik oluşmuş hastalar ve siklusun midluteal fazındaki (kontrol grubu) hastalar ile de kıyaslanmış. Endometrial kalınlık progesteron alan gebe hastalarda, kontrol grubu ve progesteron almayan hastalara göre daha yüksek $(p<0,01)$ saptanmıstır. Ortalama luteal faz serum E2 düzeyleride progesteron alan gebe grupta progesteron almayan ve kontrol grubuna göre daha yüksek $\quad(p<0,05) \quad$ saptanmıştır. Bu bulgular progesteron desteğinin endometrial kalınlığ1 arttırarak gebelik oranlarını etkilediğini, dolayısıyla endometrial reseptiviteyi arttırdığını göstermektedir.

Bizim çalışmamızda ise gebelik oluşan grupta ve gebelik oluşmayan grupta ET günü endometrial rim kalınlığ1 ve hCG günü endometrial rim kalınlığ1 arasında anlamlı farklılik saptanmamıştır. Ancak intramuskuler progesteron alan grup ile vajinal progesteron alan grup arasinda 12. gün endometrial kalınlık ölçümlerine bakıldığında istatistiksel olarak anlamlı fark bulundu $(\mathrm{p}=0,005)$. İki grup arasında ET günü endometrial kalınlık ölçümlerine bakıldığında ise anlamlı fark bulunmadı $(\mathrm{p}=0,423)$.

Bazı çalışmalarda vajinal yol ile uygulanan progesteron desteği tedavisinde luteal faz kanaması insidansında, intramuskuler kullananlara oranla artış tespit edilmiştir ${ }^{12,13}$. Aynı çalışma da luteal faz östrojen kullanımının bu kanamaları azalttı̆̆1 iddia edilmiştir. IVF sikluslarında, gebelik testi öncesi ortaya çıkan lekelenme ya da kanama, hem hekim hem de hasta üzerinde endişeye neden olabilir. Bizim çalışmamızda luteal faz kanaması insidansı değerlendirilmemiştir.

İntramüsküler kullanımda, natürel progesteronun yağdaki eriyiği verilmektedir. Bu kullanım yoluna bağlı; ağrilı enjeksiyonlar, inflamatuar reaksiyonlar ve abseler gibi yan etkiler bulunmaktadır. Bununla birlikte intramuskuler kullanıma bağlı akut eozinofilik pnömoni vakaları bildirilmiştir? ${ }^{9} \mathrm{Bu}$ nedenle hasta konforu ve yan etkiler nedeniyle luteal faz desteği açısından intramuskuler progesteron ilk tercih olarak tavsiye edilmemektedir. Çalışmamızın en önemli k1sıtlllığ retrospektif olması ve göreceli olarak az sayıda hasta içermesidir.

Sonuç olarak Vajinal progesteron kullanımı hasta konforu ve etkinlik açısından IVF uygulamalarında ilk tercih olarak, yaygın bir şekilde kullanılmaktadır. Vajinal kullanımda; uterin ilk geçiş etkisi ve karaciğerde metabolize olmaması, ayrıca anatomik yakınlığına bağlı olarak dokuda yüksek progesteron konsantrasyonları ve düşük serum düzeyleri gözlenmiştir. Çalışmamızda vajinal ve intramuskuler progesteron verilmesi ile benzer gebelik ve canlı doğum oranları elde edilmiştir, fakat vajinal yolla progesteron kullanan hastalar daha çok memnuniyet ifade etmişlerdir. Hasta konforu düşünüldüğünde vaginal progesteron kullanımı daha ön planda önerilebilirse de veriliş yollarının etkinliğini karşılaştıran daha fazla sayıda hasta ile yapılan daha çok sayıda prospektif randomize çalışmaya hala ihtiyaç vardır.

\section{KAYNAKLAR}

1. Speroff L, Fritz MA: Clinical Gynecologic Endocrinology and Infertility,7th ed. Philadelphia, Lippincott Williams \& Wilkins. 2005.

2. Pritts EA, Atwood AK. Luteal phase support in infertility treatment: A meta-analysis of the randomized trials. Hum Reprod. 2002;17:2287-99.

3. Kubik C. Luteal phase dysfunction following ovulation induction. Semin Reprod Endocrinol. 1986;4:293-9.

4. Hutchinson-Williams KA, Lunenfeld B, Diamond MP, Lavy G, Boyers SP, DeCherney AH. Human chorionic gonadotropin, estradiol, and progesterone profiles in conception and nonconception cycles in an in vitro fertilization program. Fertil Steril. 1989;52:441-5.

5. Selam B, Topçuoğlu A. Luteal faz fizyolojisi ve overi stimule eden ajanlarla değişimi. Uludağ Üniversitesi Tip Fakültesi Dergisi. 2004;30:217-20.

6. Penzias AS. Luteal phase support. Fertil Steril. 2002;77:318-23.

7. Daya S, Gunby J. Luteal phase support in assisted reproduction cycles. Cochrane Database Syst Rev. 2004;10.1002/14651858.CD004830

8. Gelbaya TA, Kyrgiou M, Tsoumpou I, Nardo LG. The use of estradiol for luteal phase support in in vitro fertilization/intracytoplasmic sperm injection cycles: A systematic review and meta-analysis. Fertil Steril. 2008;90:2116-25.

9. Bouckaert Y, Robert F, Englert Y, De Backer D, De Vuyst P, Delbaere A. Acute eosinophilic pneumonia associated with intramuscular administration of progesterone as luteal phase support after ivf: Case report. Hum Reprod. 2004;19:1806-10.

10. Phy JL, Weiss WT, Weiler CR, Damario MA. Hypersensitivity to progesterone-in-oil after in vitro fertilization and embryo transfer. Fertil Steril. 
2003;80:1272-5.

11. Veysman B, Vlahos I, Oshva L. Pneumonitis and eosinophilia after in vitro fertilization treatment. Ann Emerg Med. 2006;47:472-5.

12. Propst AM, Hill JA, Ginsburg ES, Hurwitz S, Politch J, Yanushpolsky EH. A randomized study comparing crinone $8 \%$ and intramuscular progesterone supplementation in in vitro fertilization-embryo transfer cycles. Fertil Steril. 2001;76:1144-9.

13. Yanushpolsky E, Hurwitz S, Greenberg L, Racowsky C, Hornstein MD. Comparison of crinone $8 \%$ intravaginal gel and intramuscular progesterone supplementation for in vitro fertilization/embryo transfer in women under age 40: Interim analysis of a prospective randomized trial. Fertil Steril. 2008;89:485-7.

14. Zarutskie PW, Phillips JA. A meta-analysis of the route of administration of luteal phase support in assisted reproductive technology: Vaginal versus intramuscular progesterone. Fertil Steril. 2009;92:163-9.

15. Abate A, Perino M, Abate FG, Brigandi A, Costabile L, Manti F. Intramuscular versus vaginal administration of progesterone for luteal phase support after in vitro fertilization and embryo transfer. A comparative randomized study. Clin Exp Obstet Gynecol. 1999;26:203-6.

16. Damario MA, Goudas VT, Session DR, Hammitt DG, Dumesic DA. Crinone 8\% vaginal progesterone gel results in lower embryonic implantation efficiency after in vitro fertilization-embryo transfer. Fertil Steril. 1999;72:830-6.

17. Chantilis SJ, Zeitoun KM, Patel SI, Johns DA, Madziar VA, McIntire DD. Use of crinone vaginal progesterone gel for luteal support in in vitro fertilization cycles. Fertil Steril. 1999;72:823-9.

18. Foulon W, Villena I, Stray-Pedersen B, Decoster A, Lappalainen M, Pinon JM, et al. Treatment of toxoplasmosis during pregnancy: A multicenter study of impact on fetal transmission and children's sequelae at age 1 year. Am J Obstet Gynecol. 1999;180:410-5.

19. Yanushpolsky E, Hurwitz S, Greenberg L, Racowsky C, Hornstein M. Crinone vaginal gel is equally effective and better tolerated than intramuscular progesterone for luteal phase support in in vitro fertilization-embryo transfer cycles: A prospective randomized study. Fertil Steril. 2010;94:2596-9.

20. Ragni G, Piloni S, Rossi P, Carinelli S, De Lauretis L, Vegetti W, et al. Endometrial morphology and ultrasound vascular findings. A randomized trial after intramuscular and vaginal progesterone supplementation in ivf. Gynecol Obstet Invest. 1999;47:151-6.

21. Mitwally MF, Diamond MP, Abuzeid M. Vaginal micronized progesterone versus intramuscular progesterone for luteal support in women undergoing in vitro fertilization-embryo transfer. Fertil Steril. 2010;93:554-69.

22. Kahraman S, Karagozoglu SH, Karlikaya G. The efficiency of progesterone vaginal gel versus intramuscular progesterone for luteal phase supplementation in gonadotropin-releasing hormone antagonist cycles: A prospective clinical trial. Fertil Steril. 2010;94:761-3.

23. Kınay T, Taşcı Y, Dilbaz S, Çınar Ö, Demir B, Karadağ B. The effects of serum estradiol levels and endometrial thickness measurements on pregnancy outcomes in gnrh agonist down-regulated icsi cycles. J Turk Soc Obstet Gynecol. 2010;7:289-93. 